\title{
Agricultural specialisation and the land market: an examination of the dynamics of the relationship in the Swiss Alps, c.1860-1930
}

\author{
LUIGI LORENZETTI*
}

ABSTRACT. From the latter half of the nineteenth century, mixed farming in the Alpine regions of Switzerland underwent a gradual process of specialisation. Cereal crops were phased out in favour of feed crops, livestock, viticulture and fruit farming. This article analyses the way in which the land market was affected by this increasingly specialised primary sector and asks whether this market became more efficient as a result of reduced transaction costs. Surveys have shown that the land market remained bound by the inertia inherent in the nature of landed property in the Alpine area. The connection between agricultural diversification and the land market appears to have been only partial and this suggests that the modernisation of farming did not so much alter the main balance of the market itself, as boost the circulation of plots more directly associated with the process of specialisation.

\section{INTRODUCTION}

In recent years, Alpine societies have been placed under the lenses of diverse research projects seeking to trace the relationship of these societies to the underlying farming economy, or economies. In particular, these studies have brought to light the variety of land-ownership structures, each with a different evolution over time, to be found in the many political and social configurations in place across the Alpine regions of central Europe. ${ }^{1}$ In addition, researchers have also analysed the economic, social and political relevance of the way that land was held in these regions from the fourteenth century and how this affected the livelihood of households and their reproductive systems. ${ }^{2}$

\footnotetext{
* Università della Svizzera Italiana, Mendrisio.
} 
They have drawn attention to the multiple solutions that farming households adopted in order to combine typical agricultural activities with non-farming roles, so that such households became involved in multiple activities, or 'pluriactivity'. ${ }^{3}$

Further studies have dwelt on the relationship between mountain agriculture and the market economy in the Swiss Alps. These studies have revealed the early development of forms of specialised production that were in some cases capitalist in nature, designed to maximise profits and exports. ${ }^{4}$ Having first emerged in the sixteenth century, these developments were common to many rural European regions where, as Vicente Pinilla has recently pointed out, urban demand for agricultural goods drove the specialisation and modernisation of the farming sector. Specialisation became more pronounced during the nineteenth century, as the means of transport and communication became more advanced. The lowering of customs barriers and the benefits of relative political and financial stability further promoted trade in food commodities. ${ }^{5}$ The trends toward specialisation nonetheless appear to have differed in their impact from one region to another. Unlike the Swiss lowlands, where modernisation and specialisation boosted competition, such changes failed to prevent agriculture in the country's Alpine regions, and in several other mountain regions across Europe, from sliding into decline. Fernando Collantes claims that this crisis in mountain farming was the final stage of a process, initiated by industrialisation, which led to the mountain regions becoming increasingly dependent on the more advanced economies of the plains. ${ }^{6}$

While the evolution of mountain farming across the Alps tallies in several ways with that experienced in areas more firmly integrated into a capitalist agrarian system as described above, farming in the Alpine region exhibited several specific traits. It was not uncommon for the Alpine peasant economy to develop and preserve some forms of household pluriactivity. Thus we see certain peasant households where some members pursued emigration while others remained and worked in agriculture; in other households some members worked in industry while others continued to work the family farm; in yet other households agriculture was combined with activities in tourism or in services. This allowed many small-scale farming enterprises to survive, and allowed the peasants to accumulate savings. ${ }^{7}$ The farming economy, at least in the central Alps, continued to be characterised by owner-run small-holdings, with few farms run on a 'for-profit' basis to be found beyond a small number of areas where farming had become incorporated into the production chain of 'agri-business'. One such area was the Queyras, or French Alps, where, from the early 1930 s, dairy production became integrated into the cheese-making process of the multinational group, Nestlé. ${ }^{8}$ Further examples were to be found in a few valley-bottom regions, such as Valais, Trentino 
and Alto Adige in the Italian Alps, where, from the close of the nineteenth century, an increasingly profit-oriented fruit-growing sector developed. ${ }^{9}$

Household pluriactivity and the survival of self-sufficient smallholdings were the major features characterising the link between the market and the process of modernisation of the farming sector in the Alpine region. From this point of view, the Swiss Alps provide an interesting site of inquiry for anyone trying to understand the effects of agricultural specialisation on the structure and dynamics of the land market in a particular locality. In this region specialisation saw cereal farming being replaced by increasing fodder production, cattle raising and commercial crops, especially those associated with viticulture and fruit farming. More particularly, our research sought to ascertain in what ways increasing specialisation and commercialisation within the agricultural sector influenced the distribution of agrarian land over time and whether this altered the relationship of the peasant class to the land.

Our analysis consists of five main parts. We begin, in section 2 , with an overview of the factors that historically determined the supply and demand of farming land in the Alpine areas where small farms were the norm. In section 3 we illustrate the development of specialisation within the agricultural sector in two Alpine regions in Switzerland. Subsequently we look closely at the characteristics of the land market in each of the two areas, using three indicators. In section 4 we consider the structure of real estate transactions and of land prices, in section 5 we look at the methods of payment used in land purchases and, in section 6 , the characteristics of those buying and selling land and the strategies they employed are considered. Using these indicators we try to evaluate whether the changes in the structure of the Alpine land market and the profile of those participating in it did indeed reflect an increasing degree of specialisation within agricultural production in the mountain regions between the 1860 s and the 1930 s.

\section{THE SUPPLY OF AND DEMAND FOR LAND IN THE CENTRAL ALPINE AREA}

The geographical and morphological characteristics of the soil in the Alps make land suitable for farming a rare commodity. This led to some cases of rather extreme exploitation, for example on the southern slopes of the central Alps, ${ }^{10}$ where there was high population density in the mid-nineteenth century, vast areas were deforested and used intensively as arable land. ${ }^{11}$ Such practices reflected the marked imbalance in the mountain areas between the supply of land on the one hand, and the demand for it on the other. This resulted in farmland in the Alpine areas being sold at very high prices, prices that were often well above those fetched in flatter areas where yields would generally have been somewhat greater. ${ }^{12}$ 
From a legal perspective, village communities had, since the sixteenth century, raised a range of barriers designed to restrict access to land to 'original families', families that were descended, in the patrilineal line, from indigenous families. ${ }^{13}$ This created a process of land exchange that was essentially endogamous. Indeed, many of the statutes of Central Alpine communities included measures designed to prevent the sale of either private or common land to 'foreigners' or 'incomers'. ${ }^{14}$ Although such rules were largely abolished at the beginning of the nineteenth century, when all the political and juridical structures of the ancien régime were suppressed, the Alpine property market remained essentially closed until the end of the century. The supply of land for sale was likewise constrained by community norms that prevented the break-up of a family's land by limiting the sale of parts of a property. The latter strategy was only partially successful, however, given the high degree of fragmentation typical of farming properties in the Central Alps.

Despite such restrictions, the land market was able to expand in particular circumstances. Reliable analyses conducted on the valleys of Lombardy in the nineteenth century, where the extant deeds record whether a sale was voluntary or forced, have shown that in times of economic crisis the contraction of credit fuelled an increase in the amount of land that was put up for sale, as a growing number of people were forced to give up their holdings under pressure from their creditors. ${ }^{15}$ An example is the area around Tirano, in the province of Sondrio, where, in the early 1880 s, many hundreds of forced sales and public auctions of land were recorded, the owners having defaulted on their mortgage repayments. ${ }^{16} \mathrm{~A}$ similar situation occurred in the Blenio Valley, in the canton of Ticino, where, at the beginning of the twentieth century, forced sales accounted for as much as one-third of all transactions involving land. In short, some of the increased supply of land for sale during economic crises was the consequence of debts incurred by the peasant class, who, if they could not pay these, were forced by law to either sell their land or be evicted. Together with voluntary sales, which were nevertheless also dictated by the owners' need for cash, this process contributed to the increased concentration of land in the hands of fewer owners, which tended to occur in periods of economic slump. ${ }^{17}$

Demand for land was also affected by the economic situation, reflecting the close connection between the supply of credit and the willingness to invest in land. ${ }^{18}$ The province of Sondrio, which suffered a series of agricultural crises in the latter part of the nineteenth century, is a case in point. The repeated crises were followed by a revival in the agricultural sector and surges in both the demand for land and in prices. ${ }^{19}$ Demand for land could also be influenced by the level of development and efficiency of the credit and mortgage markets in a region, as well as by the rates of interest and the amount of money in circulation. We know that in the rural societies of the 
ancien régime, prior to the nineteenth century, the land market was partially supported by informal credit, ${ }^{20}$ which ensured the liquidity necessary to guarantee transactions. In the Central Alps, as in many other rural areas of Europe, ${ }^{21}$ transactions, particularly those involving medium- to low-value land, were also paid for in cash. This suggests that those contributing to the local economy were not short of ready money, and were able to generate savings.

If we wish to fully understand the supply and demand sides of the land market in the Alpine regions, we must, as in other rural areas, ${ }^{22}$ first take into account the varying repercussions of emigration. Emigration was a key factor in the economic structure of many areas within the Alps, the fulcrum of the subsistence equilibrium on which families depended. During the second half of the nineteenth century, as a result of plummeting agricultural prices and rising external competition, demand for farmland shrank and increasing numbers of people emigrated permanently. This 'agricultural crisis-emigration' spiral meant that more marginal agricultural areas were abandoned and with them went cereal crops. ${ }^{23}$ By contrast, in areas where emigration remained only temporary or periodic, the remittances sent home by emigrants to the remaining family members fuelled demand for land, and this, in turn, accelerated the fragmentation of peasant landholdings. Eventually the high property prices being demanded for land retarded the modernisation of the agricultural sector in the Alpine region, preventing the emergence of entrepreneurial initiatives and occasionally sparking off new spirals of debt. ${ }^{24}$ As a result, Alpine farmers were often weighed down by massive mortgage debts. ${ }^{25}$

\section{SPECIALISATION WITHIN THE AGRICULTURAL SECTOR: TWO}

AREAS COMPARED

In Switzerland, from the 1870 s onwards the primary sector of the economy underwent a profound transformation. The high volume of imports of cereals from abroad pushed the country's farmers to concentrate on cattle breeding. At first, the way this trend developed depended on the proximity of centres of consumption, the towns. So farmers in the foothills of the Alps concentrated on dairy production, while those in the Alpine areas proper opted to specialise in meat production. Later on, in the first decades of the twentieth century, technical developments in milk processing and the production of cheese and condensed milk encouraged further specialisation within the agricultural sector, and as a result the Alpine regions increased their dairy production. ${ }^{26}$

Given these general trends, let us now turn to the crux of our analysis: the role that specialisation within the primary sector played in the dynamics of the market in Alpine land in Switzerland. In the face of the increasing integration of the Swiss Alpine regions into the national and international market 
economies, there were two possible trajectories for the country's agricultural sector: either it could become increasingly commercialised, or it could become increasingly conservative, relying on the viability of small, self-supporting peasant properties. ${ }^{27}$ Obviously these two options lay at the opposite ends of a spectrum, and in many cases, commercially oriented production was able to coexist alongside production for household consumption. In the Swiss canton of Valais and in the Italian province of Sondrio, for example, those working in the agricultural sector found themselves cultivating cereals for their own consumption - although this went into rapid decline in the second half of the nineteenth century-while also tending vines and fruit crops for commercial exploitation. ${ }^{28}$ On the highest land in these two areas, and in Ticino, there were several attempts to rationalise activities within the agricultural sector. For example, properties were grouped together, the organisation of the milk and cheese sector was modernised, and a greater selection of livestock was introduced. ${ }^{29}$ We must stress that the land market in the Alpine areas we studied did not operate just within the agricultural economy, or economies, but spanned a number of diverse economic systems in which pluriactivity within families was well established, with family members combining farm work with non-farm work in both the secondary and tertiary sectors. This means that the logic applied in the buying and selling of land in this region should not be viewed from the perspective of those trying to maximise agricultural production, but rather from that of families trying to optimise their income.

This viewpoint is an important one inasmuch as it invites us to consider the interaction between agricultural specialisation and the operation of the land market. On the one hand, an institutional model might suggest that the land market may have encouraged the modernisation and specialisation of agriculture, by optimising, that is reducing, transaction costs. On the other hand, however, it is possible that it was specialisation in the Alpine agricultural sector that fostered a restructuring of the way in which land was bought and sold. In the latter scenario, it is argued, restructuring was achieved when the inertia in the land market, caused both by the terms of exchange between the price of cereals and the price of other agricultural goods and by the ecological limits imposed upon the small mountain farms, was removed. It is this second hypothesis that we wish to examine by analysing a sample of notary deeds from a series referring to the sale and purchase of land in two Alpine regions in Switzerland, namely Leventina, a valley in the canton of Ticino, and Martigny in the canton of Valais (Figure 1).

We sampled deeds from three five-year periods; 1860-1864, 1890-1894 and 1920-1924, enabling us to follow the evolution of the structure of the land market in each area and to extract the relevant details for each period. ${ }^{30}$ The deeds enabled us to highlight differences in the structure of the land 


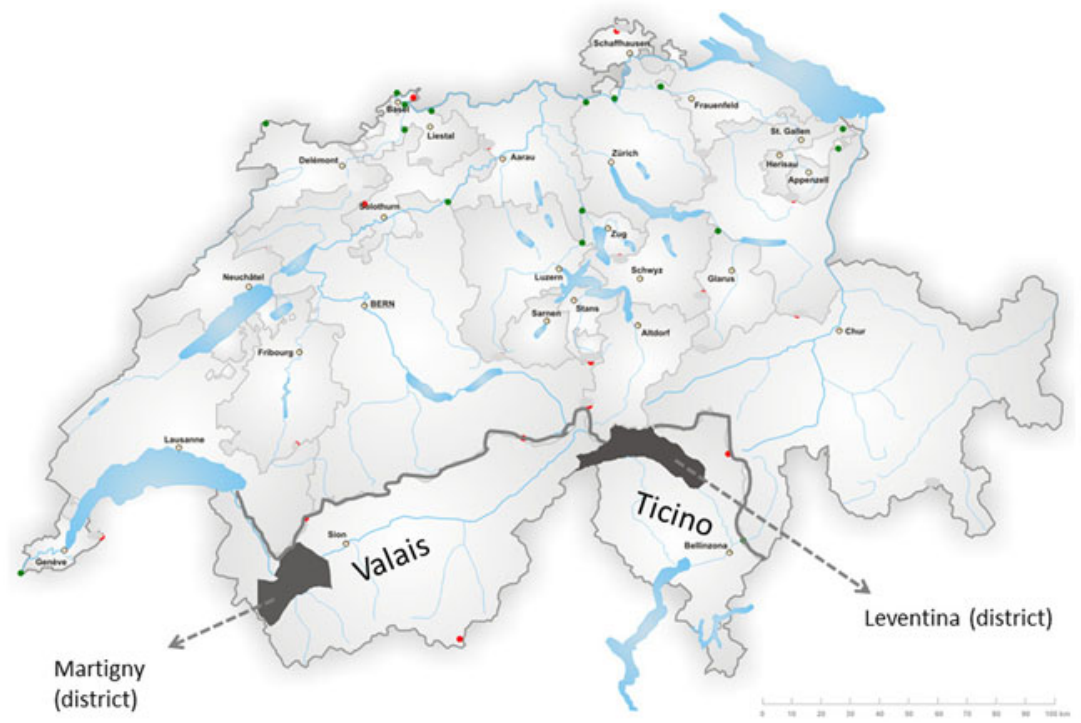

Figure 1. Switzerland, showing the cantons of Ticino and Valais. Source: http://fr. wikipedia.org/wiki/Districts_suisses (CC BY-SA 3.0)/Lorenzetti.

market in the two regions. We also ascertained whether the markets were organised around an inheritance system intended to maintain self-sufficiency in which case the land was principally a 'safe-haven' commodity, providing a secure investment, or whether they were designed to encourage an agricultural system which favoured specialisation and promoted an exchange economy involving agricultural goods being sent to market for sale.

The two regions we studied differed in a variety of ways. Although the Saint Gotthard road, one of the main routes of communication between northern and southern Europe, travels along the valley floor in Leventina, in the latter half of the nineteenth century the economy of this area was still substantially agricultural. In 1870 three-quarters (74.9 per cent) of the economically active population were engaged in the agricultural sector and, despite the arrival of the railway in 1882 and the beginning of industrial activity, this situation remained unchanged at the end of the century: in 1900, 70.3 per cent of the active population were still employed in agriculture. Over the course of the next three decades, however, this sector went through a certain amount of restructuring in Leventina. The proportion of agricultural workers fell to just 30.4 per cent of the total in 1930, the number of farms decreased from 1,342 in 1905 to 1,113 in 1929, and the number of cattle fell from 5,342 in 1901 to 4,834 in 1931. There was also greater rationalisation of cattle breeding and 
cheese-making in the district. The average number of cattle per breeder increased; the quality of the cattle was increased through more selective breeding; and new breeding techniques were introduced. Veterinary checks on the animals were established and the number of farmers insuring their animals increased. In addition more effective use was made of both the pastures in the valley and the summer alpine pastures, with less productive pastures being abandoned. Co-operative dairies and cheese factories were also established. In other words, although fewer jobs were available and less land was used by the end of the nineteenth century and the beginning of the twentieth, the improvements in agricultural productivity in Leventina led to the area's products flowing increasingly to both regional and international markets.

Somewhat similar trends may be observed in the district of Martigny. In $1870,76.6$ per cent of the economically active population were still engaged in the primary sector. While the equivalent figure was still 70 per cent in 1900 , it had dropped dramatically to 53 per cent by 1930 as a result of industrial development in the region. This decline was not, however, accompanied by a reduction in the number of farms that, thanks to the reclamation of the flood meadows along the Rhone valley, actually rose considerably, from 1,955 in 1905 to just under 2,500 in 1929. Between 1866 and 1930 the number of cattle also increased slightly, from almost 5,700 to just over 6,000 and, as in Leventina, the number of animals per breeder also increased slightly, indicating growing specialisation within the sector. The Martigny region was, however, renowned principally for its viticulture, and this reputation was consolidated in the last 20 years of the nineteenth century: the amount of land devoted to vines increased from 486 hectares in the census of 1884 to 797 hectares in the census of 1934. In addition, other types of fruit were grown on the cultivable land that had been newly reclaimed in the Rhone valley in response to the demands of the local food industries. ${ }^{31}$

We sought to find out how these changes affected the land market in each of the two regions, and to identify whether or not they made these markets more efficient. Some authors have tried to measure the efficiency of markets by estimating the transaction costs involved, taking the size of a market and the land prices as indicators, ${ }^{32}$ but we would argue that this is an almost impossible task, given how hard transaction costs are to specify. Instead, the present analysis examines three aspects of how the agrarian land market functioned: its structure, its liquidity, and the characteristics of those buying and selling.

4. THE STRUCTURE OF THE ALPINE LAND MARKET AND THE PRICE-STRUCTURES WITHIN IT

A recent survey carried out in Bresciano - a region of Lombardy situated largely within the Alpine area-has shown that changes in the structure of the 
local agrarian land market during the nineteenth century did not result in any perceptible reorganisation of farms or of their choice of crops or livestock. The owners' concerns remained centred on the evaluation of the risk entailed by their choice of crops or livestock and by their management methods. ${ }^{33}$ While this would seem to confirm that certain Alpine economies showed a degree of inertia when faced with economic change, the ability of the farming community to meet the demands of the market for agricultural produce and to take the opportunity to consolidate their businesses should not be underestimated. We were thus prompted to consider the land market as an indicator of how the choices faced by farmers changed once the economy of their rural area was drawn into a market system that was becoming increasingly integrated and widespread.

In each of the two regions examined, the structure of the land market was such that single transactions could often involve several pieces of land, each with a different use. In order to form a sufficiently precise idea of the nature of transactions involving land and to identify the type of transactions most often agreed, we need to understand the composition of the farms involved (Table 1).

The structure of the land market was quite different in the two regions, reflecting, in part, the different types of farming being practised. This can be seen in the relative amounts of land area given over to meadowland and to specialised crops, such as vines or fruit, in each area. However, the process of agricultural specialisation did not directly influence the type of land that came up for sale. Thus in Leventina-where, as has been said, there was a tendency to turn to cattle breeding as the agricultural sector gradually declined-meadows used for pasture made up more than two-thirds of the plots of land for sale during the years 1920-1924, although there had been a relative decrease in the proportion of land given over to meadow between 1860-1864 and 1890-1894. The low percentage of the total land area registered as meadowland in 1890-1894 probably reflected the contraction that the cattle-breeding industry was undergoing at that time. The increase in meadowland by the early 1920 s was probably due to the subsequent rationalisation of both breeding and forage production.

That being said, there are indicators that seem to show stability in the land market. In the three periods examined, while the average area of agricultural properties on the market increased, ${ }^{34}$ the average area of pastureland sold remained more or less steady, going from 1,129 square metres in 1860-1864, to 977 square metres in 1890-1894 and back up to 1,262 square metres in 1920-1924. Specialisation in cattle does not, therefore, seem to have led to a consolidation of the landholdings offered for sale. In the case of Martigny, despite the specialisation of the vine and fruit sectors and the increased land area devoted to such crops, the proportion of land destined 


\section{TABLE 1}

Percentage distribution of $(A)$ the number of plots of land for sale and of $(B)$ the land area covered by selected types of agriculture, in Leventina and Martigny in 1860-1864, 1890-1894 and 1920-1924

\begin{tabular}{|c|c|c|c|c|c|c|}
\hline & \multicolumn{3}{|c|}{ Leventina } & \multicolumn{3}{|c|}{ Martigny } \\
\hline & $1860-1864$ & $1890-1894$ & 1920-1924 & $1860-1864$ & $1890-1894$ & $1920-1924$ \\
\hline \multicolumn{7}{|c|}{ (A) Number of plots } \\
\hline$\%$ Meadows $^{a}$ & 58.6 & 53.5 & 67.2 & 34.8 & 39.5 & 26.4 \\
\hline$\%$ Fields $^{b}$ & 29.0 & 21.3 & 15.1 & 13.2 & 18.1 & 6.0 \\
\hline$\%$ Vineyards & 3.0 & 5.4 & 6.1 & 18.0 & 13.6 & 34.9 \\
\hline$\%$ Woods & 0.6 & 1.4 & 2.8 & 1.7 & 4.2 & 3.3 \\
\hline$\%$ Mixed & 5.7 & 10.4 & 2.7 & 9.2 & 4.8 & 1.8 \\
\hline$\%$ Other $^{c}$ & 2.7 & 3.5 & 2.6 & 11.1 & 6.6 & 13.7 \\
\hline$\%$ Uncultivated & 0.4 & 4.3 & 3.6 & 12.1 & 13.3 & 13.9 \\
\hline Total & 100.0 & 100.0 & 100.0 & 100.0 & 100.0 & 100.0 \\
\hline Number of cases & 974 & 624 & 1839 & 423 & 332 & 670 \\
\hline \multicolumn{7}{|l|}{ (B) Area } \\
\hline$\%$ Meadows $^{a}$ & 74.3 & 55.5 & 72.9 & 51.9 & 46.8 & 41.0 \\
\hline$\%$ Fields $^{b}$ & 11.4 & 7.4 & 5.2 & 5.9 & 13.4 & 4.0 \\
\hline$\%$ Vineyards & 3.5 & 7.8 & 3.2 & 5.0 & 12.4 & 15.0 \\
\hline$\%$ Woods & 0.0 & 0.1 & 5.1 & 2.9 & 4.5 & 9.1 \\
\hline$\%$ Mixed & 9.1 & 20.9 & 6.8 & 18.0 & 7.5 & 2.7 \\
\hline$\%$ Other $^{c}$ & 0.1 & 2.4 & 1.2 & 3.9 & 3.3 & 9.9 \\
\hline$\%$ Uncultivated & 1.6 & 5.8 & 5.5 & 12.5 & 12.2 & 18.2 \\
\hline Total & 100.0 & 100.0 & 100.0 & 100.0 & 100.0 & 100.0 \\
\hline $\begin{array}{l}\text { Average area } \\
\text { of a plot } \\
\text { (square metres) }\end{array}$ & 344.6 & 425.8 & 406.8 & 1230.7 & 821.6 & 1099.8 \\
\hline
\end{tabular}

${ }^{a}$ Grassland and pasture. ${ }^{b}$ Arable. ${ }^{c}$ Gardens, vegetable gardens, orchards.

Sources: For Leventina, see the State Notarial Archives-Archivio di Stato del cantone Ticino Notarile. For the period 1860-1864: Zelio Giovanni (box 4442-4444); Gianelli Agostino (box 4396); Galeppi Felice (box 4392-4395); Giudici Cipriano (box 4401-4402); Bacchi Pietro (box 4347-4348). For the period 1890-1894: Corecco Antonio (box 4363-4367bis.); Dazzoni Giovanni (box 3563); Daberti Vincenzo (box 4371-4373). For the period 1920-1924: Pattani Gottardo (box 3543-3550); Martini Gerolamo (box 45009-4524R); Dazzoni Giovanni (box 3563); Celio Enrico (box 3042); Pedrini Ferdinando (box 4224). For the region of Martigny, see the State Notarial Archives-Archives d'Etat du Valais, Notaires. For the period 18601864: Germain Ganioz, vol. 12; Gross Benjamin (box 1-2); Morand Adolphe (box 3). For the period 1890-1894: Bender Emile (box 5); Chappaz Achille (box 4); Gillioz Pierre (box 4); Roduit Emile (box 1-2); Ribordy Antoine (box 6); Défayes Joseph (box 7); Rappaz Jules (box 1-4). For the period 1920-1924: Closuit Louis, vol. 1-2; Dévayes Gilbert, vol. 56, Défayes Camille, vol. 6-7. The number of proceedings sampled are as follows: Leventina 1860-1864, 564; 1890-1894, 517; 1920-1924, 607; Martigny 1860-1864, 482; 1890-1894, 602; 1920-1924, 837. 
for fruit growing did not increase. In both 1860-1864 and 1890-1894, almost 60 per cent of the total land area put up for sale was either cultivable or under pasture; probably reflecting the demand for forage made by animal husbandry in the region. By 1920-1924, however, there had been a notable increase in the percentage of the total land area that was under vines or other fruit. Between 1890-1894 and 1920-1924, the fruit-growing sector in particular saw an increase both in the number of lots sold and in the proportion of the total agricultural land that it covered. It would seem that market demand, together with the economic policy of the Valais administration, which favoured the development of commercial agriculture, encouraged the sale of land for fruit and vines. ${ }^{35}$ Having said this, even in the Valais region, specialisation had only a limited effect on the structure of the land market and the type of properties put up for sale. Noticeably, the average area of properties placed on the market grew steadily, ${ }^{36}$ probably as a result of a process of amalgamation of plots. An uneven trend prevailed, however, in areas more particularly associated with viticulture. This was largely due to the sale of some large vineyards during the 1890-1894 period. These cases aside, commercialisation does not appear to have fuelled a surge in the average value of land under vines that was put on the market.

The impact of increased specialisation on the land market becomes more clear-cut if we take into account the relationship between the area of land for sale and its market value. In the case of Leventina, for instance, while pastureland accounted for nearly three-quarters of the total area of agricultural land for sale in 1860-1864, it amounted to only 57.5 per cent of the total value of the land sold. By 1920-1924, however, the value of this type of land climbed to 78.6 per cent of the total, further confirming the increased value of pasture over the early decades of the twentieth century. A similar evolution also occurred in Martigny: in 1860-1864 the area under vines accounted for 5 per cent of the total area of agricultural land that was put up for sale, but amounted to 22.4 per cent of the total value of such land sold. Six decades later, in 1920-1924, the vineyards had grown to make up 15.0 per cent of the total area for sale, and now represented 42.6 per cent of the value of total sales of agricultural land.

These trends are confirmed by Table 2, which shows property prices, expressed as indices based on the average value per square metre of all agricultural land on the market during each of the three chosen periods. This table thus reflects the supply of, and demand for, land.

In Leventina in 1860-1864 and 1890-1894 the average value per square metre of pasture ('meadows' in Table 2) remained below the average price of all land, but by 1920-1924 the former had come into line with the latter, confirming that a stronger demand for land suited to the cattle-breeding sector had emerged. By contrast, the growing crisis in cereal growing is confirmed by 
TABLE 2

Indices of the average value per square metre of the various property types in Leventina and Martigny in 1860-1864, 1890-1894 and 1920-1924 (general average value for each period $=100$ )

\begin{tabular}{|c|c|c|c|c|c|c|}
\hline & \multicolumn{3}{|c|}{ Leventina } & \multicolumn{3}{|c|}{ Martigny } \\
\hline & $1860-1864$ & $1890-1894$ & $1920-1924$ & $1860-1864$ & $1890-1894$ & $1920-1924$ \\
\hline Meadows $^{a}$ & 76 & 81 & 101 & 61 & 69 & 73 \\
\hline Fields $^{b}$ & 129 & 101 & 53 & 76 & 122 & 75 \\
\hline Vineyards & 191 & 163 & 292 & 149 & 161 & 125 \\
\hline Mixed & 135 & 136 & 57 & 37 & 58 & 12 \\
\hline Other ${ }^{c}$ & 199 & 113 & 33 & 104 & 45 & 62 \\
\hline Uncultivated & 15 & 71 & 158 & 91 & 99 & 87 \\
\hline Average value $^{d}$ & 0.78 & 0.91 & 2.14 & 0.76 & 0.84 & 1.77 \\
\hline
\end{tabular}

${ }^{a}$ Grassland and pasture. ${ }^{b}$ Arable. ${ }^{c}$ Gardens, vegetable gardens, orchards. ${ }^{d}$ In francs in use at indicated time.

Sources: For Leventina, see the State Notarial Archives-Archivio di Stato del cantone Ticino Notarile. For the period 1860-1864: Zelio Giovanni (box 4442-4444); Gianelli Agostino (box 4396); Galeppi Felice (box 4392-4395); Giudici Cipriano (box 4401-4402); Bacchi Pietro (box 4347-4348). For the period 1890-1894: Corecco Antonio (box 4363-4367bis.); Dazzoni Giovanni (box 3563); Daberti Vincenzo (box 4371-4373). For the period 1920-1924: Pattani Gottardo (box 3543-3550); Martini Gerolamo (box 45009-4524R); Dazzoni Giovanni (box 3563); Celio Enrico (box 3042); Pedrini Ferdinando (box 4224). For the region of Martigny, see the State Notarial Archives-Archives d'Etat du Valais, Notaires. For the period 18601864: Germain Ganioz, vol. 12; Gross Benjamin (box 1-2); Morand Adolphe (box 3). For the period 1890-1894: Bender Emile (box 5); Chappaz Achille (box 4); Gillioz Pierre (box 4); Roduit Emile (box 1-2); Ribordy Antoine (box 6); Défayes Joseph (box 7); Rappaz Jules (box 1-4). For the period 1920-1924: Closuit Louis, vol. 1-2; Dévayes Gilbert, vol. 56, Défayes Camille, vol. 6-7. The number of proceedings sampled are as follows: Leventina 1860-1864, 564; 1890-1894, 517; 1920-1924, 607; Martigny 1860-1864, 482; 1890-1894, 602; 1920-1924, 837.

the gradual drop in the relative value per square metre of arable land ('fields' in Table 2) between the 1860s and the 1920s. Initially such land could command prices almost one-third above the overall average for all types of land, but by 1920-1924 its value had dropped to only half of the overall average value. It is worth noting, however, that there was greater variation in the prices paid for each type of land in the period 1920-1924, and this was particularly marked for pastureland. While the coefficients of variation of the prices fetched for all types of farmland were 8.1 per cent in 1860-1864, 6.5 per cent in 1890-1894 and 44.2 per cent in 1929-24, the equivalent coefficients for grassland over the same three periods were 8.4 per cent, 9.2 per cent and 61.5 per cent, respectively. The causes of the increase in variation in the prices paid for land are uncertain, but the variation itself hints at the appearance of new, external economic actors within the local land market. In fact, in the early years of the 
twentieth century, several industries were set up in the southern part of the Leventina valley, boosting demand for land for industrial production and causing a sudden rise in land prices. ${ }^{37}$

The situation in Martigny appears to have been different. Although land for viticulture was very expensive in this area too, the variation in prices paid for it showed an unexpected pattern. In 1920-1924, despite the fact that more than one-third of the plots of land for sale were vineyards, as shown in Table 1, the proportion they formed of all land that was for sale had not risen dramatically since 1890-1894. Also, the cost of vineyards per square metre was only 25 per cent higher than the average price of each square metre of land in general, whereas it had been 61 per cent higher in 1890-1894. By the late 1920s the wine industry of Valais was suffering from diminished returns, ${ }^{38}$ exacerbated by competition from wines from elsewhere, a fall in home demand ${ }^{39}$ and the volatile nature of the price of wine, all of which may have contributed to the reduction in the prices paid for vineyards. The narrower spread of prices per unit for the various types of land for sale in Martigny compared with Leventina by 1920-1924 may have been a sign of a more transparent market in terms of information available to buyers and sellers. For vineyards in particular, the coefficients of variation of the prices per unit of land rose from 68.9 per cent in 1860-1864 to 85.5 per cent in 1890-1894, but then dropped to 54.6 per cent in $1920-1924$.

\section{AGRICULTURAL SPECIALISATION AND METHODS OF PAYMENT FOR LAND}

The way sales of land were paid for can also help us understand the effects of agricultural specialisation on the land market. By looking at the methods of payment we can identify the options open to those making payments, and how these depended on the type of land in which they were investing. We should point out that by the mid-nineteenth century various forms of informal credit had for a very long time been ensuring the necessary liquidity to enable the property market to function both in our two regions, and in many other rural areas of Europe. However, from the end of the nineteenth century, a drive towards the formalisation of the credit market reduced the supply of credit available to those investing in agriculture. The creation of the first bank in 1895 (the 'Caisse hypothécaire et d'épargne') helped to redirect the flow of rural savings towards more profitable investments in the industrial and financial sectors. ${ }^{40}$ This shift in investment behaviour had unexpected repercussions for the market in agricultural land. The payment arrangements shown in Table 3 suggest that in Leventina, in particular, the use of credit for land purchases gradually died out. Payments in advance or in cash, which in 1860-1864 represented only one-third (36.9 per cent) of the possible 
TABLE 3

Percentage distribution of methods of payment for land bought in Leventina and Martigny in 1860-1864, 1890-1894 and 1920-1924

\begin{tabular}{|c|c|c|c|c|c|c|}
\hline \multirow[b]{2}{*}{ Method of payment } & \multicolumn{2}{|c|}{$1860-1864$} & \multicolumn{2}{|c|}{$1890-1894$} & \multicolumn{2}{|c|}{$1920-1924$} \\
\hline & Leventina & Martigny & Leventina & Martigny & Leventina & Martigny \\
\hline$\%$ Paid in cash & 19.2 & 32.5 & 31.1 & 27.5 & 37.4 & 36.9 \\
\hline $\begin{array}{l}\text { \% Paid by deferred } \\
\text { payment }^{a}\end{array}$ & 37.7 & 37.0 & 26.6 & 38.5 & 18.4 & 48.0 \\
\hline$\%$ Paid in advance & 17.7 & 6.8 & 21.1 & 8.1 & 28.0 & 5.3 \\
\hline$\%$ Mixed payment ${ }^{b}$ & 17.7 & 17.2 & 14.2 & 17.4 & 10.0 & 8.0 \\
\hline Indeterminate & 7.7 & 6.5 & 7.1 & 8.5 & 6.2 & 1.7 \\
\hline Total & 100.0 & 100.0 & 100.0 & 100.0 & 100.0 & 100.0 \\
\hline No. of cases & 396 & 308 & 380 & 247 & 532 & 639 \\
\hline
\end{tabular}

${ }^{a}$ Including payment 'by request'. ${ }^{b}$ Cash in advance; part in advance/part deferred; part cash/ part deferred.

Sources: For Leventina, see the State Notarial Archives-Archivio di Stato del cantone Ticino Notarile. For the period 1860-1864: Zelio Giovanni (box 4442-4444); Gianelli Agostino (box 4396); Galeppi Felice (box 4392-4395); Giudici Cipriano (box 4401-4402); Bacchi Pietro (box 4347-4348). For the period 1890-1894: Corecco Antonio (box 4363-4367bis.); Dazzoni Giovanni (box 3563); Daberti Vincenzo (box 4371-4373). For the period 1920-1924: Pattani Gottardo (box 3543-3550); Martini Gerolamo (box 45009-4524R); Dazzoni Giovanni (box 3563); Celio Enrico (box 3042); Pedrini Ferdinando (box 4224). For the region of Martigny, see the State Notarial Archives-Archives d'Etat du Valais, Notaires. For the period 18601864: Germain Ganioz, vol. 12; Gross Benjamin (box 1-2); Morand Adolphe (box 3). For the period 1890-1894: Bender Emile (box 5); Chappaz Achille (box 4); Gillioz Pierre (box 4); Roduit Emile (box 1-2); Ribordy Antoine (box 6); Défayes Joseph (box 7); Rappaz Jules (box 1-4). For the period 1920-1924: Closuit Louis, vol. 1-2; Dévayes Gilbert, vol. 56, Défayes Camille, vol. 6-7. The number of proceedings sampled are as follows: Leventina 1860-1864, 564; 1890-1894, 517; 1920-1924, 607; Martigny 1860-1864, 482; 1890-1894, 602; 1920-1924, 837.

forms of payment, were used in almost two-thirds (65.4 per cent) of cases in 1920-1924. Whilst this may suggest that by the 1920s there was less opportunity to opt for a form of delayed payment, such as some formal or informal credit arrangement, it could also indicate that by this time there was greater liquidity in the market, as a result of savings accumulated by returning migrants ${ }^{41}$ and, more generally, that there were fewer buyers lacking ready cash.

Table 3 indicates that the situation in Martigny was more complex and exhibited some tendencies that contrast with those in Leventina. While the percentage of cash payments in Martigny dropped slightly in 1890-1884 compared with 1860-1864, before rising again by 1920-1924, there was a significant increase in the proportion of deferred payments between 1890-1894 and 
1920-1924, compensating for a decrease in the proportion of mixed payments. This suggests both that investors had found it easier to save, but also that informal credit, obtained privately, which was in marked decline during the period under examination, was, in part, replaced by formal credit arrangements. The use of formal credit failed, however, to ensure that the land market maintained sufficient liquidity.

In order to evaluate the different distribution of payment methods between Leventina and Martigny more effectively, we attempted to quantify the likelihood that either wholly or partially deferred payment would be used when purchasing land. The use of such methods of payment must be assumed to have involved some form of credit. Our analysis, shown in Table 4, was based on a logistic regression in which the dichotomous dependent variable is the type of payment used for the purchase of land; payment could either be 'deferred or partially deferred' or 'immediate'. The values in the table are the indicators of the change in the odds resulting from a unit change in the predictor variable. Hence, a value of 1 indicates the same probability as the reference variable of there being a 'deferred or partially deferred' payment. So, for example, the probability of payment being deferred when buying woodland was 1.58 times greater than that when buying meadowland in Leventina. In both Leventina and Martigny the likelihood that payment would be deferred increased in proportion to the value of the land being purchased. Sales involving sums in the lowest quartile were usually completed in cash, whilst those involving larger sums were more likely to be settled by deferred or mixed forms of payment.

It would appear, however, that it was significantly more difficult to make a delayed payment in the 1920-1924 period than it had been in 1860-1864. This suggests that the liquidity of the market had increased over the intervening years, but it is also possible that by the 1920s those without ready cash were struggling to find credit, or, to put it another way, the banks were failing to act as a substitute for the practice of informal credit, which was dying out. The likelihood that payment for a parcel of land would be delayed does not appear to have been affected by the use to which the land was put. For transactions of equal value in both regions, there was no statistically significant difference in the likelihood that payment would be deferred between sales of land being put to different uses. The probabilities display comparable trends in the two regions, ${ }^{42}$ suggesting that the decision to contract a debt was unrelated to the strategy of investing in a particular type of land and hard to interpret. In the case of Martigny, for example, it seems that the chance of deferring payment was smaller when buying a vineyard than when buying other types of land. This can be interpreted in several different ways. If those buying land for specialised use preferred to pay cash this may indicate that the market for such land was a fluid one. On the other hand, it may also indicate that 


\section{TABLE 4}

Factors affecting the payment being deferred or partially deferred when buying land in Leventina and Martigny, 1860-1864, 1890-1894 and 1920-1924

\begin{tabular}{|c|c|c|}
\hline & Leventina: $\operatorname{Exp}(\beta)$ & Martigny: $\operatorname{Exp}(\beta)$ \\
\hline \multicolumn{3}{|c|}{ Year $($ reference category $=1860-1864)$} \\
\hline 1890-1894 & 0.59 & 1.03 \\
\hline 1920-1924 & $0.25^{* *}$ & $0.61 * *$ \\
\hline \multicolumn{3}{|c|}{ Type of property $\left(\right.$ reference category $=$ meadow $\left.^{a}\right)$} \\
\hline Field $^{b}$ & 1.10 & 1.09 \\
\hline Vineyard & 0.64 & 0.82 \\
\hline Wood & 1.58 & 1.53 \\
\hline Mixed & 0.71 & 0.97 \\
\hline Other & 0.38 & 1.31 \\
\hline \multicolumn{3}{|c|}{ Quartile value $\left(\right.$ reference category $=\mathbf{Q 1}^{c}$ ) } \\
\hline Q2 & 1.17 & $1.63 *$ \\
\hline Q3 & 1.49 & 1.53 \\
\hline Q4 & $2.65^{*}$ & $2.04 *$ \\
\hline \multicolumn{3}{|c|}{ Residence of seller (reference category $=$ other) } \\
\hline District (Leventina/Martigny) & 1.02 & 0.92 \\
\hline \multicolumn{3}{|c|}{ Residence of buyer (reference category $=$ other) } \\
\hline District (Leventina/Martigny) & $3.37 * *$ & 0.69 \\
\hline \multicolumn{3}{|c|}{ Seller type (reference category $=$ single man) } \\
\hline Single woman & 0.71 & $1.46^{*}$ \\
\hline Family members & 1.11 & 1.63 \\
\hline Other & 1.16 & 1.38 \\
\hline \multicolumn{3}{|c|}{ Buyer type (reference category $=$ single $\operatorname{man}$ ) } \\
\hline Single woman & 0.51 & 0.73 \\
\hline Family members & 1.25 & 0.91 \\
\hline Other & $3.07 * *$ & 0.51 \\
\hline Square metre & 1.00 & $1.00 * *$ \\
\hline Constant & 0.44 & 0.66 \\
\hline
\end{tabular}

${ }^{a}$ Grassland and pasture. ${ }^{b}$ Arable. ${ }^{c}$ Q1 indicates the lowest quartile.

$* p<0.05, * * p<0.01$.

the only transactions occurring were limited to participants with ready cash, and excluded those who had restricted access to credit. ${ }^{43}$ In short, even when methods of payment are taken into consideration, the effects of specialisation on the agricultural sector were so varied that they are difficult to interpret unambiguously. The impression is, however, that the relationship between the willingness of investors to contract a debt and their decision on which type of land to invest in did not depend on any entrepreneurial logic but rather on when an opportunity to invest arose and the availability, or not, of ready cash at that point. 
6. THE GEOGRAPHY OF AND ACTORS IN THE ALPINE LAND MARKET

The last series of indicators selected to capture the effects of specialisation on the workings of the land market concerns those participating in the sales, their motivations and their strategies for intervention in the market. In the latter half of the nineteenth century, the land market in the two Alpine regions surveyed continued to be largely endogamous; land circulated between buyers and sellers residing in the same community or, at least, in the same region. In Leventina, for example, 75 to 80 per cent of land transactions were endogamous during each of the three periods surveyed and in the Martigny region between 68 and 87 per cent of such transactions were endogamous. Agricultural specialisation did not, therefore, appear either to widen the area across which land was traded or to raise the number of investors from outside the local region. In Leventina the proportion of buyers domiciled outside the valley, which had been around 6.6 per cent in 1860-1864, slid to 5.5 per cent in 1890-1894 before creeping up to 7.5 per cent in 1920-1924. The proportion of vendors domiciled outside the valley rose more noticeably: in 1860-1864 they formed 10.6 per cent of all vendors, but by 1890-1894 this figure had risen to 14.2 per cent. In 1920-1924 the figure had scarcely changed: 'outsiders' formed just 14.3 per cent of all vendors. In contrast, as the number of people emigrating from the Leventina valley to other parts of Europe and beyond rose, an increasing number of those leaving sold their land to their immediate families or to other relatives being left behind. Emigration from a district thus helped to concentrate the ownership of land back into the hands of the residents. The same mechanism can be observed in Martigny, although here the people who carried out sales from outside the district were either domiciled in the neighbouring Swiss cantons of Vaud and Geneva, or were women who had left their home canton after getting married.

In addition, it seems that, in both regions, purchases of land for specialist forms of farming tended to be the preserve of local residents, while people resident outside the district were far more inclined to sell this type of property. In the Alps, therefore, the market in land used for specialised types of farming seems to have acted to realign landownership in a way that benefited the resident population.

As previously mentioned, before the middle of the nineteenth century inheritance practices and land management in the central Alps frequently worked together to postpone the partition of inherited estates, thus slowing down the process of fragmentation of family property and encouraging labour resources within the family group to be pooled. The property market therefore largely dealt with undivided properties. This being the case, it would seem reasonable to expect that many sellers and buyers would not be individuals but groups of closely related individuals; brothers and sisters, say, or parents 
and children. In the transactions we sampled, such 'related groups' became less predominant over time, as shown in Table 5. In Leventina and in Martigny the incidence of sales involving groups of relations gradually decreased between 1860-1864 and 1920-1924, due mainly to the drop in the number of sales made by groups of siblings.

There seems to be no clear change over time in how individuals and groups participated in the land market. Our first impression is that the greater participation by individuals was unrelated to agricultural specialisation. We can, however, by examining the details of the sales summarised in Table 5, identify a certain number of trends that suggest the strategies adopted by those involved in the land market. In the Leventina valley, individual men buying agricultural land were more likely to purchase meadows or grassland than other types of land, at least within the three periods investigated. In contrast, single men who were selling land were less likely to sell grassland plots than plots for other forms of agriculture. In the Martigny region, although men operated mostly on an individual basis when purchasing and selling land for viticulture, they were much less likely to purchase such land than meadows, arable fields or mixed-use land. The reason for this is probably to be found in the fact that the latter sorts of property were cheaper to buy, and, once bought, the land could then be converted, or reconverted, wherever possible, into vineyards. In the absence of land registry data, we were unable to test this assumption, although the increase in the number of vineyard plots in Martigny, shown in Table 1, would seem to support it.

Further evidence of the strategies pursued by different groups when buying and selling land is provided by the balance between the value of total sales and total purchases of the different types of land by people acting individually, together with relatives, or as unrelated groups. Table 6 indicates that in two out of the three periods, in both Leventina and Martigny, market operations concerning individuals generally show a positive balance; that is, the overall value of purchases was higher than that of sales, compared with the negative overall balances which were most often found when transactions concerned groups of relatives. Participation in the land market seems to have become increasingly individualised and unfettered by the practices of indivisibility. Once again the differences between the two regions and the varied impact of the different types of agricultural specialisation on the local land market become apparent. In Martigny, the value of the balance of the 'family' investments in vineyards was generally negative, while in the case of individual investors it was consistently positive. The growing individualisation of investment in vineyards would seem to indicate the success of specialisation in this sector in terms of opening up the land market.

The picture was rather different in Leventina because in 1860-1864 and 1920-1924, but not in 1890-1894, the value of individual transactions 


\section{TABLE 5}

Percentage distribution of the types of person or persons selling and buying land in (A) Leventina and (B) Martigny in 1860-1864,1890-1894 and 1920-1924

\begin{tabular}{|c|c|c|c|c|c|c|}
\hline \multirow[b]{2}{*}{ Type } & \multicolumn{3}{|c|}{ Sellers } & \multicolumn{3}{|c|}{ Purchasers } \\
\hline & $1860-1864$ & 1890-1894 & $1920-1924$ & $1860-1864$ & 1890-1894 & $1920-1924$ \\
\hline \multicolumn{7}{|l|}{ (A) Leventina } \\
\hline Single men & 55.6 & 52.1 & 44.7 & 75.0 & 72.1 & 70.3 \\
\hline Single women & 23.7 & 23.4 & 31.4 & 10.4 & 10.8 & 11.7 \\
\hline Siblings & 9.6 & 7.4 & 7.0 & 8.8 & 7.4 & 8.8 \\
\hline Married couples & 1.8 & 0.8 & 0.2 & 1.0 & 1.1 & 0.9 \\
\hline Parents and offspring & 4.0 & 8.4 & 10.0 & 0.5 & 1.3 & 1.7 \\
\hline Heirs & 1.3 & 1.8 & 1.5 & - & - & 0.6 \\
\hline $\begin{array}{l}\text { Public or private } \\
\text { bodies }\end{array}$ & 0.3 & 1.6 & 4.0 & 0.5 & 3.7 & 4.6 \\
\hline Other & 3.8 & 4.4 & 1.3 & 3.8 & 3.7 & 1.5 \\
\hline Total & 100.0 & 100.0 & 100.0 & 100.0 & 100.0 & 100.0 \\
\hline No. of cases & 474 & 380 & 532 & 474 & 380 & 532 \\
\hline \multicolumn{7}{|l|}{ (B) Martigny } \\
\hline Single men & 54.9 & 51.0 & 37.4 & 82.1 & 71.3 & 76.8 \\
\hline Single women & 24.0 & 33.2 & 15.2 & 8.1 & 14.2 & 13.0 \\
\hline Siblings & 8.1 & 5.3 & 2.7 & 4.2 & 6.5 & 3.1 \\
\hline Married couples & 1.9 & 4.0 & 1.6 & - & 1.6 & 0.6 \\
\hline Parents and offspring & 6.5 & 3.6 & 1.4 & 1.0 & - & 0.3 \\
\hline Heirs & 1.3 & 1.6 & 1.7 & - & - & - \\
\hline $\begin{array}{l}\text { Public or private } \\
\text { bodies }\end{array}$ & 2.3 & 0.4 & 35.8 & 1.3 & 3.2 & 1.8 \\
\hline Other & 1.0 & 0.8 & 4.2 & 3.2 & 3.2 & 4.4 \\
\hline Total & 100.0 & 100.0 & 100.0 & 100.0 & 100.0 & 100.0 \\
\hline No. of cases & 308 & 247 & 639 & 308 & 247 & 639 \\
\hline
\end{tabular}

Sources: For Leventina, see the State Notarial Archives-Archivio di Stato del cantone Ticino Notarile. For the period 1860-1864: Zelio Giovanni (box 4442-4444); Gianelli Agostino (box 4396); Galeppi Felice (box 4392-4395); Giudici Cipriano (box 4401-4402); Bacchi Pietro (box 4347-4348). For the period 1890-1894: Corecco Antonio (box 4363-4367bis.); Dazzoni Giovanni (box 3563); Daberti Vincenzo (box 4371-4373). For the period 1920-1924: Pattani Gottardo (box 3543-3550); Martini Gerolamo (box 45009-4524R); Dazzoni Giovanni (box 3563); Celio Enrico (box 3042); Pedrini Ferdinando (box 4224). For the region of Martigny, see the State Notarial Archives-Archives d'Etat du Valais, Notaires. For the period 18601864: Germain Ganioz, vol. 12; Gross Benjamin (box 1-2); Morand Adolphe (box 3). For the period 1890-1894: Bender Emile (box 5); Chappaz Achille (box 4); Gillioz Pierre (box 4); Roduit Emile (box 1-2); Ribordy Antoine (box 6); Défayes Joseph (box 7); Rappaz Jules (box 1-4). For the period 1920-1924: Closuit Louis, vol. 1-2; Dévayes Gilbert, vol. 56, Défayes Camille, vol. 6-7. The number of proceedings sampled are as follows: Leventina 1860-1864, 564; 1890-1894, 517; 1920-1924, 607; Martigny 1860-1864, 482; 1890-1894, 602; 1920-1924, 837. 
TABLE 6

Balance between the total value of purchases of land and the total value of sales of land in francs, for different types of land and by whether the transaction involved individuals, a family group or another sort of group: Leventina and Martigny, 1860-1864, 1890-1894 and 1920-1924

\begin{tabular}{|c|c|c|c|c|c|c|c|c|c|}
\hline \multirow[b]{2}{*}{ Type of land } & \multicolumn{3}{|c|}{$1860-1864$} & \multicolumn{3}{|c|}{$1890-1894$} & \multicolumn{3}{|c|}{$1920-1924$} \\
\hline & Individual & Family & Other & Individual & Family & Other & Individual & Family & Other \\
\hline \multicolumn{10}{|l|}{ Leventina } \\
\hline Meadows $^{b}$ & -2736 & 1996 & 740 & 1910 & -1537 & -373 & -4380 & -1212 & 5592 \\
\hline Fields $^{c}$ & 592 & -383 & -209 & -259 & -113 & 372 & 2059 & -1588 & -471 \\
\hline Vineyards & -11 & 101 & -90 & -49 & -117 & 166 & 1892 & -1892 & 0 \\
\hline Mixed or other & -9254 & 7814 & 1440 & 8429 & -10401 & 1972 & 11748 & -9436 & -2312 \\
\hline Total & -12308 & 9527 & 2781 & 10696 & -12833 & 2137 & 11618 & -14427 & 2809 \\
\hline \multicolumn{10}{|l|}{ Martigny } \\
\hline Meadows $^{b}$ & 7348 & -5038 & -2310 & -4528 & 2569 & 1959 & -5760 & -10109 & 15869 \\
\hline Fields $^{c}$ & 801 & -801 & 0 & -1037 & -1608 & 2645 & -315 & -665 & 980 \\
\hline Vineyards & 6050 & -806 & -5244 & 3317 & -3092 & -225 & 23565 & -41936 & 18371 \\
\hline Mixed or other & -655 & -4525 & 5180 & -250 & 465 & -215 & 38557 & -13204 & -25353 \\
\hline Total & 13849 & -11475 & -2374 & -2498 & -1666 & 4164 & 56327 & -66194 & 9867 \\
\hline
\end{tabular}

${ }^{a}$ Positive figures indicate that the value of purchases of land was greater than the value of sales of land. ${ }^{b}$ Grassland and pasture. ${ }^{c}$ Arable.

Sources: For Leventina, see the State Notarial Archives - Archivio di Stato del cantone Ticino Notarile. For the period 1860-1864: Zelio Giovanni (box 4442-4444); Gianelli Agostino (box 4396); Galeppi Felice (box 4392-4395); Giudici Cipriano (box 4401-4402); Bacchi Pietro (box 4347-4348). For the period 1890-1894: Corecco Antonio (box 4363-4367bis.); Dazzoni Giovanni (box 3563); Daberti Vincenzo (box 4371-4373). For the period 1920-1924: Pattani Gottardo (box 3543-3550); Martini Gerolamo (box 45009-4524R); Dazzoni Giovanni (box 3563); Celio Enrico (box 3042); Pedrini Ferdinando (box 4224). For the region of Martigny, see the State Notarial Archives - Archives d'Etat du Valais, Notaires. For the period 1860-1864: Germain Ganioz, vol. 12; Gross Benjamin (box 1-2); Morand Adolphe (box 3). For the period 1890-1894: Bender Emile (box 5); Chappaz Achille (box 4); Gillioz Pierre (box 4); Roduit Emile (box 1-2); Ribordy Antoine (box 6); Défayes Joseph (box 7); Rappaz Jules (box 1-4). For the period 1920-1924: Closuit Louis, vol. 1-2; Dévayes Gilbert, vol. 56, Défayes Camille, vol. 6-7. The number of proceedings sampled are as follows: Leventina 1860-1864, 564; 1890-1894, 517; 1920-1924, 607; Martigny 1860-1864, 482; 1890-1894, 602; 1920-1924, 837. 
involving meadowland showed a negative balance. In other words, it was precisely the areas devoted to crops that showed disinvestment on the part of the individual farmer. Instead, areas of fields that were less oriented towards commercial production yielded a positive investment balance. Once again, Leventina's economy seems to belie the link between specialisation in the agricultural sector and increased ownership and management by individuals, rather than families or kin.

\section{CONCLUSIONS}

It is in economically marginal areas that tensions between local and 'global' processes may be identified, such tensions standing out in greater relief in such areas than in more economically central parts of society. ${ }^{44}$ In this context, the Alpine regions of Switzerland offer ample opportunity to explore how the land market changed during the course of the economic modernisation of so-called 'marginal societies'. ${ }^{45}$

The analysis reported here has attempted to evaluate how increasing specialisation in the agricultural sector influenced the dynamics of the land market and the farmers' relationship to the land in the Alpine regions. Our research has shown that, over the course of the second half of the nineteenth century, agriculture in the two areas surveyed experienced notable progress towards specialisation - despite taking different routes, and with the process proceeding at different intensities - thanks to the stimulus of the increasingly international food market. While specialisation brought a degree of rationalisation and modernisation to production processes within agriculture, the same cannot be said for the land market that remained constrained by an inertia brought about by the nature and structure of land ownership in the Alpine area. ${ }^{46}$

Despite a movement towards greater concentration of property, land continued to be highly fragmented, particularly where there was specialisation in the farming sector. Moreover, the strategies of those buying and selling land failed to reveal that they supported, or had a clear preference for, specialisation. Indeed, specialisation seems to have resulted from the cultivation of new crops or technical improvements, rather than from the reorganisation of land by means of the market towards a more 'rational' use of the soil. Our analysis thus appears to indicate that it was possible for agrarian modernisation to take place and for the agricultural sector to be integrated into a widening market system, even if the prevailing systems and structures of land exchange remained unchanged. Thus, while on the one hand the legal framework of land ownership in the Swiss Alps exerted a profound influence on the land market, on the other hand it did not hinder the rise of entrepreneurship in the agricultural market. 


\section{ACKNOWLEDGEMENTS}

This paper was written as part of the Swiss National Science Foundation project no. 101511-109484. I would like to thank Jean Cowling and Simona Cain for the translation from Italian into English.

\section{ENDNOTES}

1 J. Mathieu, History of the Alps, 1500-1900: environment, development, and society (Morgantown, West Virginia, 2009) [trans. by M. Vester; originally published as Geschichte der Alpen, 1500-1900 (Vienna, 1998)], chap. 3.

2 L. Lorenzetti and R. Merzario, Il fuoco acceso. Famiglie e migrazioni alpine nell'Italia d'età moderna (Rome, 2005) and the recent synthesis by D. Albera, Au fil des générations. Terre, pouvoir et parenté dans l'Europe alpine (XIVe-XXe siècles) (Grenoble, 2011).

3 On the Alps, see especially D. R. Holmes, 'A peasant-worker model in a northern Italian context', American Ethnologist 10, 4 (1983), 734-48; F. Ramella, Terra e telai. Sistemi di parentela e manifattura nel Biellese dell'Ottocento (Turin, 1984); R. Merzario, Il capitalismo nelle montagne. Strategie famigliari nella prima fase di industrializzazione nel Comasco (Bologna, 1989); A. Tanner, Spulen, Weben, Sticken: die Industrialisierung in Appenzell Ausserrhoden (Zurich, 1982); A.-L. Head-König, 'Introduction-l'industrie et les femmes dans les montagnes de l'Europe: modèles d'insertion et de fonctionnement des ménages', in N. Valsangiacomo and L. Lorenzetti eds., Donne e lavoro. Prospettive per una storia delle montagne europee (XVIII-XX secc.) (Milan, 2010), 97-113; L. Lorenzetti, 'Ruralité, industrie et formes de pluriactivité', Histoire, Economie et Société 3 (2012), 15-34.

4 See for example, J.-F. Bergier, Histoire économique de la Suisse (Lausanne, 1984); N. Grass, 'Vieh- und Käseexport aus der Schweiz in angrenzende Alpenländer besonders im 16. und 17. Jahrhundert', in L. Carlen and G. Imboden, Wirtschaft des alpinen Raums im 17. Jahrhundert (Brig, 1988), 113-77; A.-L. Head-König, 'Les alpages en Suisse: typologie et accès à la propriété, rapport aux marchés, migrations (XVIe-début XIXe siècle)', in S. Cavaciocchi ed., Il mercato della terra, secc. XIII-XVIII. Atti della "trentacinquesima settimana di studi" dell'Istituto internazionale di storia economica "F. Datini" Prato, 5-9 maggio 2003 (Florence, 2004), 315-36.

5 V. Pinilla, 'The impact of markets in the management of rural land', in V. Pinilla ed., Markets and agricultural change in Europe from the 13th to the 20th century (Turnhout, 2009), 11-36.

6 F. Collantes, 'Farewell to the peasant republic: marginal rural communities and European industrialization', Agricultural History Review 54, II (2006), 257-73; F. Collantes, 'Rural Europe reshaped: the economic transformation of upland regions, 1850-2000', Economic History Review 62, 2 (2009), 306-23.

7 See, for example, Merzario, Il capitalismo nelle montagne; P. Judet, 'Du paysan à l'horloger. Histoire sociale d'un Faucigny pluri-actif (1850-1930)', Ruralia 9 (2001), http://ruralia.revues. org/247; L. Lorenzetti, Destini periferici. Modernizzazione, risorse e mercati in Ticino, Valtellina e Vallese 1850-1930 (Udine, 2010); P. Corner, Contadini e industrializzazione. Società rurale e impresa in Italia dal 1840 al 1940 (Rome and Bari, 1993); J.-L. Mayaud, La petite exploitation rurale triomphante. France XIXe siècle (Paris, 1999).

8 H. G. Rosenberg, A negotiated world: three centuries of change in a French Alpine community (Toronto, 1988).

9 For Trentino and Alto Adige, see R. Raffaelli, 'Il lento affermarsi delle specializzazioni produttive', in A. Leonardi ed., La regione Trentino-Alto Adige/Südtirol nel XX, vol. 2. Economia. Le traiettorie dello sviluppo (Trento, 2009), 139-49; C. Lorandini, 'L'agricoltura trentina dalla 
coltivazione promiscua alla specializzazione produttiva', in A. Leonardi and P. Pombeni eds., Storia del Trentino, vol. VI. L'età contemporanea. Il Novecento (Bologna, 2005), 487-514. For Valais, see H. Thurre, Les domaines de la Sarvaz. Une agriculture valaisanne en mutation au XXe siècle (Sion, 2013).

10 Here we are referring to the current Swiss cantons of Ticino and Valais, although part of the latter lies in Germany, as well as the alpine valleys of Lombardy.

11 Mathieu, History of the Alps, chap. 3.

12 For the Italian alpine area, see A. Fornasin, Ambulanti, artigiani e mercanti. L'emigrazione della Carnia in età moderna (Verona, 1998), 45-61; Lorenzetti and Merzario, Il fuoco acceso, 87,110 .

13 These 'original families' had the right, as joint owners, to participate in the management and use of the common lands and other resources of the community.

14 Lorenzetti and Merzario, Il fuoco acceso, 70-80.

15 For example in the Alpine valleys of Ticino we estimate that in the period $1830-1840$ at least 10 per cent of land sales were the result of people being obliged to sell to pay off debts. This proportion could increase to over 30 per cent, however, in times of crisis. See L. Lorenzetti, 'Endettement paysan, demande foncière, spéculation. Les vallées tessinoises au XIX siècle', in G. Béaur, Ch. Dessureault and J. Goy eds., Familles, terres, marchés. Logiques économiques et stratégies dans les milieu ruraux (XVIIe-XXe siècles) (Rennes, 2004), 185-98. See also P. Tedeschi, 'Marché foncier, crédit et activités manufacturières dans les Alpes. Le cas des vallées de la Lombardie orientale (XVIII-XIX siècles)', Histoire des Alpes-Storia delle Alpi-Geschichte der Alpen 12 (2007), 247-59.

16 Supplemento al foglio periodico della R. Prefettura di Sondrio 1881, 1883-1885, 1888. In the five years under consideration there were 300 forced sales or public auctions in total, or around 60 per year, whereas in 'normal' years the number dropped to fewer than 10.

17 E. Rullani, L'economia della provincia di Sondrio dal 1871 al 1971 (Sondrio, 1973).

18 G. Postel-Vinay, 'La terra a rate? Osservazioni sul credito e il mercato fondiario in Francia nel XIX secolo', Quaderni Storici 65 (1987), 579-97. For the Alps, see, for example, G. Piluso, 'Terra e credito nell'Italia settentrionale nel Settecento: mercati, istituzioni e strumenti in prospettiva comparata', in Cavaciocchi, Il mercato della terra, 743-64.

19 Rullani, L'economia della provincia di Sondrio, 93-4, 108-11, 165-7.

20 G. Béaur, 'Foncier et crédit dans les sociétés préindustrielles. Des liens solides ou des chaines fragiles?', Annales Histoire Sciences Sociales 6 (1994), 1411-28; G. Béaur, 'Credit and land in eighteenth-century France', in T. Lambrecht and P. Schofield eds., Credit and the rural economy in North-Western Europe, c. 1200-c.1850 (Turnhout, 2009), 153-67.

21 G. Béaur, 'Des sols contre de la terre. L'argent dans les transactions foncières au XVIIIe siècle', in P. Minard and D. Voronoff eds., L'argent des campagnes. Echanges, monnaie, crédit dans la France rurale d'ancien régime (Paris, 2003), 171-83.

22 Ibid.

23 Lorenzetti, Destini periferici, 146-7.

24 See, for example, M. Scapaccino, Studio delle condizioni economiche ed agrarie della provincia di Sondrio (Vicenza, 1992), 58-63.

25 E. Bassi, La Valtellina (provincia di Sondrio). Sue condizioni morali, economiche, industriali, agricole, politiche, sanitarie. Usi, costumi, lingua, belle arti, avanzi antichi, uomini illustri (Milan, 1890), 53.

26 T. Frey, 'Der Strukturwandel der Schweizerischen Landwirtschaft nach 1850 im Licht der Thünen'schen Kreise', Traverse: Zeitschrift für Geschichte 1 (2008), 31-48.

27 See P. P. Viazzo, Upland communities. Environment, population and social structure in the Alps since the sixteenth century (Cambridge, 1989), chap. V. The author consciously refers 
to a process of 'peasantification' that touched many alpine communities in the first half of the twentieth century.

28 On viticulture in Valais, see A.-D. Zufferey-Périsset ed., Histoire de la vigne et du vin en Valais. Des origines à nos jours (Sierre-Salquenen, 2009). For the Valtellina, see D. Zoia, Vite e vino in Valtellina e Valchiavenna. La risorsa di una valle alpina (Sondrio, 2004).

29 Lorenzetti, Destini periferici, 67-84.

30 For Leventina, see the State Notarial Archives-Archivio di Stato del cantone Ticino Notarile. For the period 1860-1864: Zelio Giovanni (box 4442-4444); Gianelli Agostino (box 4396); Galeppi Felice (box 4392-4395); Giudici Cipriano (box 4401-4402); Bacchi Pietro (box 4347-4348). For the period 1890-1894: Corecco Antonio (box 4363-4367bis.); Dazzoni Giovanni (box 3563); Daberti Vincenzo (box 4371-4373). For the period 1920-1924: Pattani Gottardo (box 3543-3550); Martini Gerolamo (box 45009-4524R); Dazzoni Giovanni (box 3563); Celio Enrico (box 3042); Pedrini Ferdinando (box 4224). For the region of Martigny, see the State Notarial Archives - Archives d'Etat du Valais, Notaires. For the period 1860-1864: Germain Ganioz, vol. 12; Gross Benjamin (box 1-2); Morand Adolphe (box 3). For the period 1890-1894: Bender Emile (box 5); Chappaz Achille (box 4); Gillioz Pierre (box 4); Roduit Emile (box 1-2); Ribordy Antoine (box 6); Défayes Joseph (box 7); Rappaz Jules (box 1-4). For the period 1920-1924: Closuit Louis, vol. 1-2; Dévayes Gilbert, vol. 56, Défayes Camille, vol. 6-7. The number of proceedings sampled are as follows: Leventina 1860-1864, 564; 1890-1894, 517; 1920-1924, 607; Martigny 1860-1864, 482; 1890-1894, 602; 1920-1924, 837.

31 G. Arlettaz, 'Les transformations économiques et le développement du Valais 1850-1914', Groupe Valaisan de science humaines, Développement et mutation du Valais (Sion, 1976), 34. Among the factories was the Saxon food-processing plant, which opened in 1885 and gave work to hundreds of people, mainly from Valais, in the 1920s.

32 B. Van Bavel, T. de Moor and J. L. Van Zanden, 'Introduction: factor markets in global economic history', Continuity and Change 24, 1 (2009), 9-21, here 14.

33 P. Tedeschi, 'Marché foncier et systèmes de production agricoles dans l'Italie du nord au XIXe siècle: le cas de la Lombardie orientale', European Review of History/Revue Européenne d'Histoire 5 (2008), 459-77.

34 The average surface area of land exchanges increases from 913 square metres in 1860-1864, to 1470 square metres in 1890-1894 and 1579 square metres in 1920-1924.

35 S. Métrailler, 'L'Etat face au développement de l'agriculture dans la vallée du Rhône durant la seconde moitié du XIXe siècle (1860-1914)' (unpublished mémoire de licence, University of Fribourg, 1978); A. Clavien, 'La modernisation du Valais, 1848-1914', in Histoire du Valais, t. 3 (Sion, 2002), 581-635.

36 The average area of land under vines that changed hands on the land market rose from 321 square metres in 1860-1864 to 812 square metres in 1890-1894 before dropping to 651 square metres in 1920-1924.

37 G. Pini, 'La Basse Léventine. L'industrialisation en milieu rural' (unpublished mémoire de licence, University of Geneva, 1977), 37-41.

38 Production costs in the viticulture sector in 1929 are estimated to have been 4,160 francs per hectare or 70 cents per litre of grape juice, allowing for a yield of 0.6 litres per square metre. This suggests an average selling price of between 0.75 and 1.05 francs per litre (the vineyard is Fendant white quality), indicating the low yield of this sector of the local economy. See J.-J. Germanier, 'Aspects de la viticulture valaisanne de l'entre-deux-guerres' (unpublished mémoire de licence, University of Fribourg, 1978), 18-20.

39 For example, the average annual wine consumption per head in Switzerland is estimated to have dropped from 88 litres in 1893-1902 to 47 litres in 1929. This is accounted for mainly by the increase in the price of local wines, which encouraged people to consume less. 
40 Lorenzetti, Destini periferici, 181-90. In other contexts, conversely, private credit-including that of religious institutions - supported the development of crafts and manufacturing activities and consequently the alpine economy and that of the Pre Alps. See, for example, P. Tedeschi, 'Sale or gratuitous transfer? Conveyance of family estates in a manufacturing village: Lumezzane in the eighteenth and nineteenth centuries', Continuity and Change 23, 3 (2008), 429-55.

41 Lorenzetti, Destini periferici, 181-90.

42 We observe, however a trend towards the postponement of payment when areas of forest were being purchased. In contrast, when vineyards were being purchased, payment upfront was encouraged.

43 Although referring to Brittany, in France, F. Boudjaaba makes some interesting appraisals of the different forms of payment for the purchase of land in Des paysans attachés à la terre? Familles, marchés et patrimoines dans la région de Vernon (1750-1830) (Paris, 2008), $306-23$.

44 A. Tribess, 'La modernité sarde: une nouveauté toute relative', Ruralia 7 (2000), http://ruralia. revues.org/document177.html

45 On the theme of marginal spaces, see S. Pollard, Marginal Europe. The contribution of marginal lands since the Middle Ages (New York, 1997).

46 A.-L. Head-König, 'Property rights in Switzerland during the eighteenth and nineteenth centuries. A possible explanation for different types of economic change?', in G. Béaur, P. Schofield, J.-M. Chevet and M. T. Pérez Pícazo eds., Property rights, land market and economic growth in the European countryside (Turnhout, 2013), 515-35 (524-31).

\section{FRENCH AND GERMAN ABSTRACTS}

Spécialisation agricole et marché foncier: leur dynamique relationnelle dans les Alpes suisses, 1860-1930

Dans les Alpes suisses, à partir de la seconde moitié du 19e siècle, le système agricole jusque-là caractérisé par sa mixité, entama un processus graduel de spécialisation. Les cultures céréalières furent éliminées en faveur des cultures fourragères, de l'élevage, de la viticulture et de l'arboriculture fruitière. Cet article étudie la manière dont le marché foncier a été affecté par un secteur primaire de plus en plus spécialisé et si ce marché est devenu plus efficace en raison de coûts de transaction réduits. L'enquête a montré que, dans la région alpine, le marché de la terre restait bridé par l'inertie inhérente à la nature de la propriété foncière. Le lien entre diversification agricole et marché foncier semble n'avoir été que partiel. Ce résultat suggère que la modernisation de l'agriculture n'a pas beaucoup modifié l'équilibre majeur du marché lui-même, mais a stimulé la circulation des parcelles associées directement au processus de spécialisation.

Landwirtschaftliche Spezialisierung und der Bodenmarkt: eine Untersuchung der Dynamik der Beziehungen in den Schweizer Alpen, ca. 1860-1930

Ab der zweiten Hälfte des 19. Jahrhunderts durchlief die Landwirtschaft in den Alpenregionen der Schweiz einen schrittweisen Spezialisierungsprozess. Getreideanbau wurde zugunsten von Futterpflanzen, Viehwirtschaft, Weinbau und Obstanbau zurückgefahren. Dieser Beitrag analysiert, auf welche Weise der ländliche 
Bodenmarkt durch diese zunehmende Spezialisierung des primären Sektors beeinflusst wurde, und fragt danach, ob dieser Markt infolge der reduzierten Transaktionskosten effizienter wurde. Untersuchungen haben gezeigt, dass der ländliche Bodenmarkt durch die für ländliche Grundstücke im Alpenraum typische Schwerfälligkeit eingeschränkt blieb und die Verbindung zwischen landwirtschaftlicher Diversifikation und dem Bodenmarkt nur partiell bestand, was darauf hindeutet, dass die landwirtschaftliche Modernisierung nicht so sehr das allgemeine Marktgleichgewicht selbst veränderte, sondern vielmehr die Zirkulation derjenigen Grundstücke erhöhte, die direkt mit dem Spezialisierungsprozess verknüpft waren. 